\title{
АУТОМАТИЗОВАНО ПРОЈЕКТОВАҢЕ ТРАКАСТИХ ТРАНСПОРТЕРА СА НОСЕЋОМ КОНСТРУКЦИЈОМ ОД АЛУМИНИЈУМСКИХ ПРОФИЛА
}

\section{AUTOMATED DESIGN OF BELT CONVEYORS WITH SUPPORTING STRUCTURE OF ALUMINUM PROFILES}

Никола Бодрожић, Драган Живанић, Никола Иланковић, Факултет техничких наука, Нови Сад

\section{Област - МАШИНСТВО}

Кратак садржај - Тема рада јесте аутоматизовано пројектовање тракастог транспортера са носећом конструкцијом од алуминијумских конструкиионих профила.. На почетку су дате теоријске поставке у вези са тракастим транспортерима, обрађени су најбитнији подсклопови и дат је преглед појединих изведених решења. Након тога је дат детаљан прорачун носеће конструкиије тракастог транспортера, као и прорачун потребне снаге погонског електромотора за погон транспортне траке. На крају је објашьен начин моделирања и аутоматизованог пројектовања.

Кључне речи: тракасти транспортер, прорачун носеће конструкиије, $3 D$ моделиране

Abstract - The subject of this paper is the automated design of the belt conveyor with supporting structure of aluminum profiles. First, theoretical basis about the belt conveyor was given. The most important elements of the conveyor were described and analyzed. The overview of existing solutions was also given. After, a detailed calculation of the conveyor construction was given and the calculation of the required drive power was presented. At the end it was described how the $3 D$ design process was conducted.

Keywords: belt conveyor, calculation of the load-bearing structure, $3 D$ design

\section{1. УВОД}

Тракасти транспортери са носећом конструкцијом од Alu профила („лаки“ транспортери) су уређаји непрекидног транспорта који се најчешће користе за транспорт комадног терета или упакованих кутија у којима се налази одређен број транспортних јединица, а ретко расутог терета. Терет се најчешће транспортује у хоризонталном и мало нагнутом правцу помоћу гумене транспортне траке која представља носећи и вучни елемент. Прилагодљиви су широком спектру примене, од лаких специфичних фармацеутских производа, преко кутија и пакета у индустријама хране и пића. Такође, налазе примену у производним и процесним индустријама, аутоматизованим системима, итд.

\section{НАПОМЕНА:}

Овај рад проистекао је из мастер рада чије ментор је био др Драган Живанић, ванр. проф.

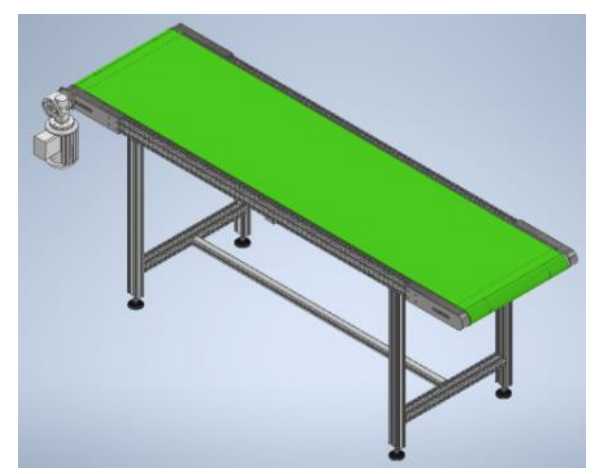

Слика 1. Приказ тракастог транспортера са носећом конструкиијом од Аlи профила

Основне предности оваквих транспортера су релативно мали отпори кретања, односно мала потрошња енергије, лака и једноставна конструкција и као таква заузима мало простора, висока исплативост, лако одржавање и мали експлоатациони трошкови велика поузданост у раду, савремен дизајн и бешуман рад.

Такође, поседује и недостатке као што су осетљивост на ударе у конструкцију, непогодност формирања сложених траса у хоризонталној равни као и у простору, ограничен нагиб транспортовања са стандардним тракама, осетљивост на хемијске утицаје као и на повишене температуре.

\section{2. ОПИС ПРОБЛЕМАТИКЕ}

Према пројектном задатку, за транспорт комадног терета, у аутомобилској индустрији предвиђен је тракасти транспортер са конструкцијом од алуминијумских профила. За транспортер је било потребно прорачунати и извршити избор његових карактеристичних елемената, прорачунати носивост конструкције и извршити аутоматизовано пројектовање транспортера у $3 D$ програму, за следеће податке:

- дужина транспортера од $1 \mathrm{~m} \div 6 \mathrm{~m}$;

- ширина транспортне траке од 0,5 m $\div 1 \mathrm{~m}$;

- маса материјала по дужном метру од $10 \mathrm{~kg} \div$ $100 \mathrm{~kg}$;

- брзина транспортне траке максимално $15 \mathrm{~m} / \mathrm{min}$ односно 0,25 m/s ;

- носећа конструкција од алуминијумског профила: главни носач light $30 \times 60 \mathrm{~mm}$;

- погонски механизам - произвођача MÄDLER. 


\section{3. ПРИБЛИЖАН ПРОРАЧУН ТРАКАСТОГ ТРАНСПОРТЕРА}

Силе у траци тракастог транспортера одређују се методом обиласка контуре крећући се од једне, произвољно изабране тачке, у смеру њеног кретања.

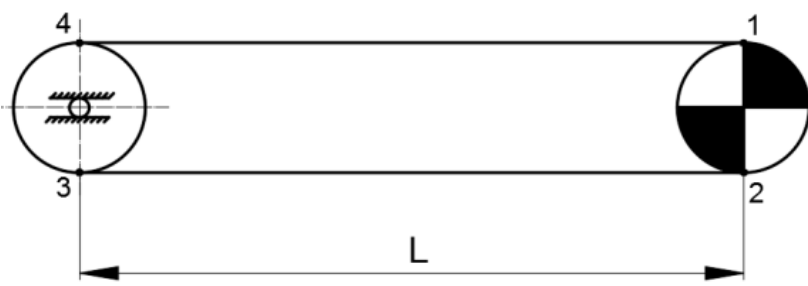

Слика 2. Шема трасе тракастог транспортера

Израчунавајући отпоре на појединим деловима транспортера, полазећи од силазне тачке са погонског бубња (тачка 2), добијају се силе у означеним карактеристичним тачкама у функцији $S_{2}$. На овај начин се добија систем једначина чији је број за један мањи од броја карактеристичних тачака. За добијање решења потребно је увести још један, додатни услов. Код тракастих транспортера где се трака ослања на радној страни на ваљке, овај услов се формира на основу критеријума којим је одређена минимална вредност силе на радној страни траке, чиме се обезбеђују услови да не дође до расипања материјала са траке због превеликог угиба.

Код предметних тракастих транспортера то није случај, тако да ће овај услов послужити за одређивање сила у траци за приближан прорачун, који ће послужити као основа за завршни прорачун. Приближан прорачун је детаљно одрађен у мастер раду, а након њега је урађен и прорачун потребне снаге погонског електромотора, што је дало само оквирне вредности потребних снага док се не изврши завршни прорачун тракастог транспортера.

\section{4. ЗАВРШНИ ПРОРАЧУН ТРАКАСТОГ TPAНСПОРТЕРА}

Након урађеног приближног прорачуна потребно је одредити степен сигурности против проклизавања траке. Теорија преноса оптерећења путем трења између бубња и траке заснива се на Ојлеровом обрасцу који дефинише однос сила у наилазном и силазном краку траке у тренутку почетка њеног проклизавања по бубњу [1].

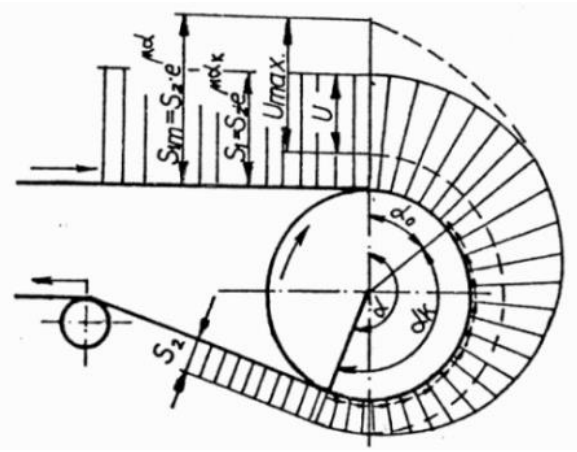

Слика 3. Механизам преноса оптерећена

Степен сигурности против проклизавања добија се према следећем изразу:

$$
\varphi=\frac{S_{2} \cdot\left(e^{\mu \alpha}-1\right)}{S_{1}-S_{2}} \geq 1,25
$$

где су:

$S_{1}$ - сила у наилазном краку траке;

$S_{2}$ - сила у силазном краку траке;

$\mu$ - коефицијент трења између траке и бубња;

$\alpha$ - обухватни угао траке по бубњу.

Како је израчунати степен сигурности против проклизавања знатно изнад дозвољене вредности, то значи да је сама транспортна трака превише оптерећена, односно превише затегнута. То може довести до смањења њеног радног века, али и стварања додатних оптерећења на вратила и лежајеве што може изазвати потребу за већим димензијама вратила, а самим тим и лежајева.

Због свега наведеног приступило се смањењу минимално дозвољене силе у траци, али тако да се и даље одржи степен сигурности у дозвољеним границама. На основу степена сигурности врши се поновно израчунавање претходно израчунатих сила у траци, односно њихова корекција. Сила у наилазном краку траке, у том случају, може се записати као збир силе у силазном краку траке и свих отпора дуж трасе, односно:

$$
S_{1}=S_{2}+\Delta S_{2-3}+\Delta S_{3-4}+\Delta S_{4-1}
$$

Поступак тражења сила у карактеристичним тачкама трасе транспортера детаљно је обрађена у оквиру мастер рада.

Након корекције сила у траци приступило се одређивању стварне потребне снаге погонског електромотора према следећем изразу:

$$
P=\frac{U \cdot v}{\eta}
$$

где су:

$U$ - обимна сила која је једнака разлици сила у наилазној и силазној тачки са погонског бубња; $\eta$ - степен искоришћења погонског механизма; $v$ - брзина кретања траке транспортера.

Након одређених снага електромотора, што је детаљно урађено у оквиру мастер рада, дат је приказ потребних и стандардних снага електромотора у зависности од масе материјала по дужном метру и дужине трасе

\begin{tabular}{|c|c|c|c|c|c|c|c|}
\hline \multirow{2}{*}{\multicolumn{2}{|c|}{$\begin{array}{l}\text { Cнага } \\
P[k W]\end{array}$}} & \multicolumn{6}{|c|}{ Маса материјала по дужном метру } \\
\hline & & $10[\mathrm{~kg}]$ & $20[\mathrm{~kg}]$ & $30[\mathrm{~kg}]$ & $40[\mathrm{~kg}]$ & $50[\mathrm{~kg}]$ & $100[\mathrm{~kg}]$ \\
\hline \multirow{6}{*}{ 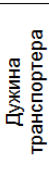 } & $1[\mathrm{~m}]$ & 0,015 & 0,025 & 0,034 & 0,044 & 0,054 & 0,103 \\
\hline & $2[\mathrm{~m}]$ & 0,029 & 0,049 & 0,068 & 0,087 & 0,107 & 0,203 \\
\hline & $3[\mathrm{~m}]$ & 0,044 & 0,073 & 0,102 & 0,130 & 0,159 & 0,303 \\
\hline & $4[\mathrm{~m}]$ & 0,058 & 0,097 & 0,135 & 0,173 & 0,212 & 0,403 \\
\hline & $5[\mathrm{~m}]$ & 0,073 & 0,121 & 0,169 & 0,216 & 0,264 & 0,503 \\
\hline & $6[\mathrm{~m}]$ & 0,088 & 0,145 & 0,202 & 0,259 & 0,317 & 0,603 \\
\hline
\end{tabular}
транспортера.

Табела 1. Потребне снаге електромотора 
Табела 2. Стандардне снаге електромотора

\begin{tabular}{|c|c|c|c|c|c|c|c|}
\hline \multirow{2}{*}{\multicolumn{2}{|c|}{$\begin{array}{l}\text { Снага } \\
P[k W]\end{array}$}} & \multicolumn{6}{|c|}{ Маса материјала по дужном метру } \\
\hline & & $10[\mathrm{~kg}]$ & $20[\mathrm{~kg}]$ & $30[\mathrm{~kg}]$ & $40[\mathrm{~kg}]$ & $50[\mathrm{~kg}]$ & $100[\mathrm{~kg}]$ \\
\hline \multirow{6}{*}{ 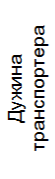 } & $1[\mathrm{~m}]$ & 0,12 & 0,12 & 0,12 & 0,12 & 0,12 & 0,12 \\
\hline & $2[\mathrm{~m}]$ & 0,12 & 0,12 & 0,12 & 0,12 & 0,12 & 0,25 \\
\hline & $3[\mathrm{~m}]$ & 0,12 & 0,12 & 0,12 & 0,25 & 0,25 & 0,37 \\
\hline & $4[\mathrm{~m}]$ & 0,12 & 0,12 & 0,25 & 0,25 & 0,25 & 0,75 \\
\hline & $5[\mathrm{~m}]$ & 0,12 & 0,25 & 0,25 & 0,25 & 0,37 & 0,75 \\
\hline & $6[\mathrm{~m}]$ & 0,12 & 0,25 & 0,25 & 0,37 & 0,37 & 0,75 \\
\hline
\end{tabular}

\section{5. ПРОРАЧУН НОСЕЪЕ КОНСТРУКЦИЈЕ ТРАКАСТОГ ТРАНСПОРТЕРА}

У оквиру ове тачке следи опис прорачуна целе носеће конструкције.

\section{1. Прорачун главног носача носеће конструкције-доказ чврстоће}

Према пројектном задатку, као главни носач тракастог транспортера користи се алуминијумски профил за који је потребно извршити прорачун носивости, односно спровести доказ чврстоће носача. Носач се моделира као проста греда која је оптерећена континуалним оптерећењем $q$.

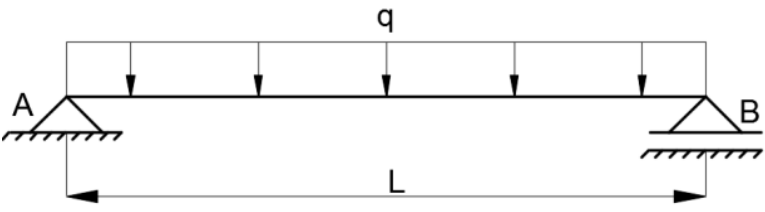

Слика 4. Модел главног носача

Како транспортер има два подужна главна носача, за прорачун је узет један носач и на њега је редуковано оптерећење које потиче од терета. Међутим, у обзир је узет најнеповољнији случај, односно претпоставка да ће на један главни носач да се пренесе $60 \%$ укупног оптерећења. Разлог томе је могући неправилни рад траке при раду транспортера, тј. њеног закошења (шетање у подужном правцу) и неравномерне расподеле терета по ширини траке. На овај начин моделирано оптерећење иде на страну сигурности конструкције. Допуштени напони, нормални и тангенцијални се одређују на основу следећих образаца [2]:

$$
\begin{gathered}
\sigma_{d o p}=\frac{R_{p 0,2 \%}}{v_{1}} \\
\tau_{d o p}=\frac{R_{p 0,2 \%}}{v_{1} \cdot \sqrt{3}}
\end{gathered}
$$

где су:

$R_{p 0,2 \%}-$ конвенцијални напон течења;

$v_{1}$ - степен сигурности за I случај оптерећења: оптерећење при нормалном раду без ветра.

Овде је дат табеларни приказ добијених резултата упоредних напона.

\begin{tabular}{|c|c|c|c|c|c|c|c|}
\hline \multirow{2}{*}{\multicolumn{2}{|c|}{$\begin{array}{c}\text { Напон } \\
\sigma_{u}[\mathrm{MPa}]\end{array}$}} & \multicolumn{6}{|c|}{ Маса материјала по дужном метру } \\
\hline & & $10[\mathrm{~kg}]$ & $20[\mathrm{~kg}]$ & $30[\mathrm{~kg}]$ & $40[\mathrm{~kg}]$ & $50[\mathrm{~kg}]$ & $100[\mathrm{~kg}]$ \\
\hline \multirow{6}{*}{ 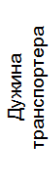 } & $1[\mathrm{~m}]$ & 1,06 & 2,13 & 3,2 & 4,26 & 5,33 & 10,66 \\
\hline & $2[\mathrm{~m}]$ & 4,26 & 8,53 & 12,8 & 17,06 & 21,32 & 42,65 \\
\hline & $3[\mathrm{~m}]$ & 9,6 & 19,2 & 28,8 & 38,4 & 48 & 96 \\
\hline & $4[\mathrm{~m}]$ & 17 & 34,12 & 51,2 & 68,25 & 85,3 & 170,61 \\
\hline & $5[\mathrm{~m}]$ & 26,65 & 53,31 & 80 & 106,63 & 133,3 & 266,6 \\
\hline & $6[\mathrm{~m}]$ & 38,4 & 76,8 & 115,17 & 153,55 & 191,95 & 383,9 \\
\hline
\end{tabular}

Табела 3. Приказ резултата упоредних напона
Са слике се види за које дужине трасе и масе материјала је радни напон мањи од дозвољеног, тако да је ту чврстоћа задовољена што значи да неће доћи до лома главног носача. За оне дужине трасе и масе материјала где је радни напон већи од дозвољеног напона, што значи да ће доћи до лома главног носача тј. чврстоћа није задовољена, потребно је поставити још један ослонац на средини распона греде. Усвајање већег (јачег) профила није решење, јер је по пројектном задатку захтев да се главни носач ради само од једне врсте Alu профила. Увођењем трећег ослонца добија се статички неодређен систем о ком ће бити речи у наредном поглављу.

\section{2. Прорачун главног носача носеће конструкције, статички неодређен систем-доказ чврстоће}

У претходном поглављу се видело да је за неке случајеве потребан још један ослонац како би чврстоћа главног носача била задовољена, односно да би радни напони били у границама дозвољеног.

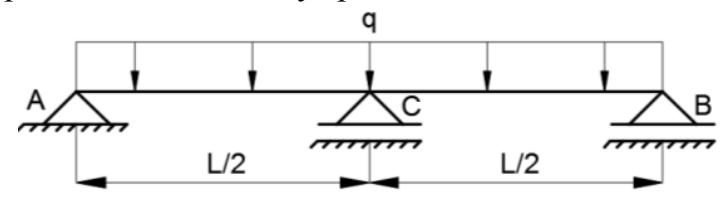

Слика 5. Модел главног носача са три ослонщ̧а

Приликом писања једначина равнотеже види се да је ово систем са 4 непознате реакције везе -3 једначине равнотеже = једноструко статички неодређен систем. Према теорији из Отпорности материјала реакција ослонца која је додата (средњи ослонац) се проглашава за статички прекобројну величину. Да би овај систем једначина био решив, потребно је увести четврту (допунску) једначину, која представља геометријски услов деформације, у ком се каже да је реакција (додатог) ослонца једнака нули, односно:

$$
Y_{C}=0
$$

На основу теорије из Отпорности материјала статички неодређен систем се решава по принципу суперпозиције који је дат следећом једначином:

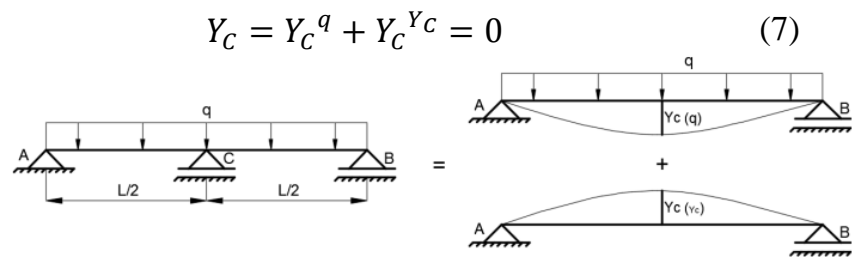

Слика 6. Принщии суперпозищије

Комплетан поступак детаљно је урађен у оквиру мастер рада, а овде је дат приказ добијених резултата упоредних напона који нису, а који су након конструктивних измена задовољили ослов да је упоредни напон мањи од дозвољеног.

\begin{tabular}{|c|c|c|c|c|}
\hline \multirow{2}{*}{\multicolumn{2}{|c|}{$\begin{array}{c}\text { Напон } \\
\sigma_{u}[M P a]\end{array}$}} & \multicolumn{3}{|c|}{ Маса материјала по дужном метру } \\
\hline & & $40[\mathrm{~kg}]$ & $50[\mathrm{~kg}]$ & $100[\mathrm{~kg}]$ \\
\hline \multirow{3}{*}{ 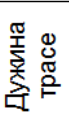 } & $4[\mathrm{~m}]$ & 1 & 1 & 170,61 \\
\hline & $5[\mathrm{~m}]$ & 1 & 133,3 & 266,6 \\
\hline & $6[\mathrm{~m}]$ & 153,55 & 191,95 & 383,9 \\
\hline
\end{tabular}

Табела 4. Упоредни напони који нису задовољили услов $\sigma_{u} \leq \sigma_{\text {dор }}$ 
Табела 5. Упоредни напони који задовољавају услов $\sigma_{u} \leq \sigma_{\text {dop }}$

\begin{tabular}{|c|c|c|c|c|}
\hline \multirow{2}{*}{\multicolumn{2}{|c|}{$\begin{array}{c}\text { Напон } \\
\sigma_{u}[M P a]\end{array}$}} & \multicolumn{3}{|c|}{ Маса материјала по дужном метру } \\
\hline & & \multirow{2}{*}{$\frac{40[\mathrm{~kg}]}{/}$} & \multirow{2}{*}{$\frac{50[\mathrm{~kg}]}{/}$} & \multirow{2}{*}{$\frac{100[\mathrm{~kg}]}{42,66}$} \\
\hline \multirow{3}{*}{ 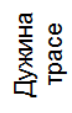 } & $4[\mathrm{~m}]$ & & & \\
\hline & $5[\mathrm{~m}]$ & I & 33,32 & 66,65 \\
\hline & $6[\mathrm{~m}]$ & 38,4 & 48 & 96 \\
\hline
\end{tabular}

\section{3. Прорачун укрућења носеће конструкције- доказ чврстоће}

Укрућење се моделира као проста греда на два ослонца, која је оптерећена континуалним оптерећењем $q$, као у поглављу 4.1.

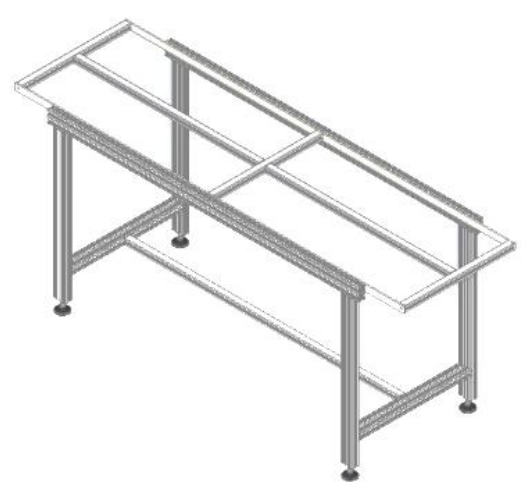

Слика 7. Приказ конструкичије са укрућењем

Са слике се види да се на транспортеру налази једно попречно укрућење које образује два поља, претпоставка је да то укрућење преузима половину оптерећења, а да се на преостала два поља преноси по четвртина укупног оптерећења. Како је укрућење сложеног попречног пресека потребно је пронаћи момент инерције тог пресека, као и његово тежиште да би се могли одредити радни напони и који делују у пресеку.

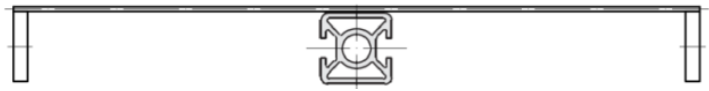

Слика 8. Укрућење носеће конструкиије сложеног попречног пресека

Овде су дати табеларни резултати упоредних напона који делују унутар укрућења конструкције.

Табела 6. Приказ резултата упоредних напона који делују у укрућењу конструкиије

\begin{tabular}{|c|c|c|c|c|c|c|c|}
\hline \multirow{2}{*}{\multicolumn{2}{|c|}{$\begin{array}{c}\text { Напон } \\
\sigma_{u}[\mathrm{MPa}]\end{array}$}} & \multicolumn{6}{|c|}{ Маса материјала по дужном метру } \\
\hline & & $10[\mathrm{~kg}]$ & $20[\mathrm{~kg}]$ & $30[\mathrm{~kg}]$ & $40[\mathrm{~kg}]$ & $50[\mathrm{~kg}]$ & $100[\mathrm{~kg}]$ \\
\hline \multirow{6}{*}{ 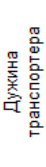 } & $1[\mathrm{~m}]$ & 0,28 & 0,561 & 0,841 & 1,122 & 1,402 & 2,805 \\
\hline & $2[\mathrm{~m}]$ & 0,658 & 1,316 & 1,975 & 2,633 & 3,292 & 6,584 \\
\hline & $3[\mathrm{~m}]$ & 1,036 & 2,072 & 3,108 & 4,145 & 5,181 & 10,362 \\
\hline & $4[\mathrm{~m}]$ & 1,414 & 2,828 & 4,242 & 5,656 & 7,070 & 14,141 \\
\hline & $5[\mathrm{~m}]$ & 1,792 & 3,584 & 5,376 & 7,168 & 8,960 & 17,920 \\
\hline & $6[\mathrm{~m}]$ & 2,169 & 4,339 & 6,509 & 8,679 & 10,849 & 21,698 \\
\hline
\end{tabular}

\section{6. ПРОРАЧУН ПОГОНСКОГ ВРАТИЛА ТРАКАСТОГ ТРАНСПОРТЕРА}

Да би се обезбедио правилан рад и да не би дошло до пуцања вратила и нежељених хаварија код тракастог транспортера, потребно је извршити прорачун погонског вратила. Прорачун се врши за најтеже услове рада, што иде на страну сигурности вратила, односно претпоставља се да је оптерећење које изазива савијање вратила распоређено са 40-60 \%. Овакав распо- ред оптерећења се може јавити као последица бочног померања траке услед неравномерно распоређеног терета по траци или нехомогености саме транспортне траке. Прорачун вратила се врши за случај, када је познат момент савијања $(M)$ и момент увијања $(T)$, који у овом случају потиче од погонског електромотора. У табели је дата препорука материјала за израду вратила, пречник вратила је рачунски добијен, $d=25 \mathrm{~mm}$.

Табела 7. Препорука материјала за израду вратила

\begin{tabular}{|c|c|c|c|c|c|c|c|}
\hline \multirow{2}{*}{\multicolumn{2}{|c|}{$\begin{array}{c}\text { Материјал } \\
\text { вратила }\end{array}$}} & \multicolumn{6}{|c|}{ Маса материјала по дужном метру } \\
\hline & & $10[\mathrm{~kg}]$ & $20[\mathrm{~kg}]$ & $30[\mathrm{~kg}]$ & $40[\mathrm{~kg}]$ & $50[\mathrm{~kg}]$ & $100[\mathrm{~kg}]$ \\
\hline \multirow{6}{*}{ 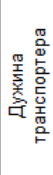 } & $1[\mathrm{~m}]$ & CF53 & CF53 & CF53 & CF53 & CF53 & CF53 \\
\hline & $2[\mathrm{~m}]$ & CF53 & CF53 & CF53 & CF53 & CF53 & CF53 \\
\hline & $3[\mathrm{~m}]$ & CF53 & CF53 & CF53 & CF53 & CF53 & $34 \mathrm{CrNiMo6}$ \\
\hline & $4[\mathrm{~m}]$ & CF53 & CF53 & CF53 & CF53 & CF53 & 34CrNiMo6 \\
\hline & $5[\mathrm{~m}]$ & CF53 & CF53 & CF53 & CF53 & 34CrNiMo6 & 34CrNiMo6 \\
\hline & $6[\mathrm{~m}]$ & CF53 & CF53 & CF53 & $34 \mathrm{CrNiMo6}$ & $34 \mathrm{CrNiMo6}$ & $34 \mathrm{CrNiMo6}$ \\
\hline
\end{tabular}

\section{7. ЗАКЉУЧАК}

Тракасти транспортери представљају уређаје непрекидног транспорта који се користе за транспорт различитих врста материјала више десетина година. При њиховом пројектовању тежи се повећању радног века у смислу правилног димензионисања његових делова и правилним одабиром стандардних компоненти (лежајеви, завртњеви, итд.), смањењу трошкова... У раду су дефинисане многе савремене изведбе неких техничких решења, формирана је квалитетна подлога за израду техничке документације уз поштовање правила дефинисаних правилницима и стандардима. Такође, у раду су дефинисане подлоге за аутоматизацију појединих сегмената пројеката тракастих транспортера, који би требали да постану уобичајени у инжењерској пракси.

\section{8. ЛИТЕРАТУРА}

[1] Д. Живанић: Непрекидни и аутоматизовани транспорт - скрипта, Нови Сад 2019.

[2] Зоран Петковић, Давор Острић: Маталне конструкције у машиноградњи 1, Београд 1996.

\section{Кратка биографија:}

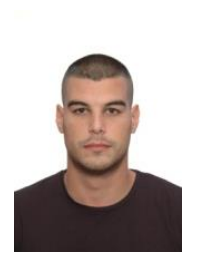

Никола Бодрожић рођен у Сремској Митровици 1996. год. Дипломирао 2019. године на Факултету техничких наука, смер машинство, на којем исте године уписује мастер студије на усмерењу за машинске конструкције, транспортне системе и логистику.

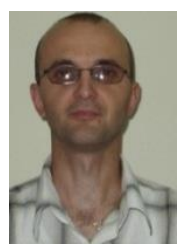

Драган Живанић рођен у Сремској Митровици 1972. год. Докторирао је 2012. год, од 2014. ради као доцент, а од 2019. као ванредни професор на Факултету техничких наука у Новом Саду.

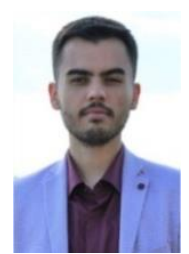

Никола Иланковић рођен у Суботици 1994 год. Завршио мастер академске студије 2018. године на Факултету техничких наука и исте године уписао докторске студије машинства. Запослен је у звању асистент мастер на Факултету техничких наука у Новом Саду. 